\title{
VIABILIDADE E CONSERVAÇÃO DE PÓLEN DE TRÊS ANONAS COMERCIAIS $\left({ }^{1}\right)$
}

\author{
JOSÉ EMILIO BETTIOL NETO $\left({ }^{2}\right)$; MARIANA DEL NERO $\left({ }^{2,4}\right)$; RYOSUKE KAVATI $\left({ }^{3}\right)$; \\ CECÍLIA ALZIRA FERREIRA PINTO-MAGLIO $\left({ }^{2 *}\right)$
}

\begin{abstract}
RESUMO
O pólen das anonas comerciais, cherimóia (Annona cherimola Mill.), fruta-do-conde, pinha ou ata (Annona squamosa L.) e atemóia (Annona cherimola X Annona squamosa) têm período de viabilidade reduzido. Este fato, aliado à ocorrência de dicogamia protogínica nessas plantas, demanda metodologias de conservação que promovam maior longevidade ao pólen. Objetivou-se neste estudo a aplicação de técnicas de conservação do pólen dessas fruteiras. O pólen foi coletado de flores em estádio macho e conservado em nitrogênio líquido $\left(-196{ }^{\circ} \mathrm{C}\right)$ e geladeira $\left(4-5^{\circ} \mathrm{C}\right)$. Utilizaram-se amostras de pólen dessecadas e não dessecadas, coletadas em período seco e úmido do ano. Pólen recém-coletado e não submetido à conservação, pólen fresco (PF), foi considerado padrão. O pólen amanhecido (PA) foi utilizado após 12 horas da coleta. A viabilidade polínica foi avaliada através de testes de coloração com o corante Alexander, germinação in vitro e polinização em campo. Para a germinação, utilizaram-se dois meios de cultura, o meio A e o BK e a viabilidade foi avaliada pela taxa de emissão de tubo polínico. O PF coletado em período úmido revelou maior viabilidade em relação ao do período seco. Nos testes de germinação in vitro ocorreu emissão de tubos polínicos para as amostras de PF e PA nas primeiras 12 horas. A emissão de tubos polínicos decaiu com o tempo de conservação. Nos testes de germinação in vitro e polinização em campo, o pólen das três fruteiras, conservado em geladeira, proporcionou maior viabilidade que o conservado em nitrogênio. Nas polinizações obtiveram-se frutificações com PF e PA coletados em período úmido e em período seco e ausência de frutificações nas polinizações com pólen conservado além de três dias, tanto em nitrogênio como na geladeira.
\end{abstract}

Palavras-chave: Criopreservação, coloração com Alexander, germinação de pólen in vitro, viabilidade de pólen.

\section{ABSTRACT \\ VIABILITY AND CONSERVATION OF POLLEN FROM TREE COMMERCIAL ANNONAS}

Pollen of commercial anonas, cherimoya (Annona cherimola Mill.), curstad apple (Annona squamosa L.) and atemoya (Annona cherimola X Annona squamosa) has a short viability time. This fact associated with the occurrence of protogynous dichogamy in these plants demands methodologies for pollen conservation that increases pollen longevity. The objective of this study was to apply pollen storage procedures to these fruit trees. The pollen was collected from flowers at male stage and conservation assays were performed in liquid nitrogen $\left(-196^{\circ} \mathrm{C}\right)$ and refrigerator $\left(4-5^{\circ} \mathrm{C}\right)$. Pollen samples were submitted to desiccation and some were not desiccated and were collected during dry and humid periods of the year. The freshly collected pollen without desiccation was denominated fresh pollen (PF) and was used as control. The freshly collected pollen that was used in the assays 12 hours after collection was

$\left(^{1}\right)$ Recebido para a publicação em 8 de abril de 2008 e aceito em 8 de julho de 2009.

$\left({ }^{2}\right)$ Instituto Agronômico (IAC/APTA/SAA), Caixa Postal, 28, 13020-970 Campinas (SP) Brasil. E-mail: bettiolneto@iac.sp.gov.br; maglio@iac.sp.gov.br $\left(^{*}\right)$ Autora correspondente.

$\left({ }^{3}\right)$ Coordenadoria de Assistência Técnica Integral (CATI), Lins (SP). E-mail: edr.lins@cati.sp.gov.br;

$\left.{ }^{4}\right)$ Bolsista de Iniciação Científica da FAPESP. 
denominated dawned pollen (PA). Pollen viability was evaluated by staining tests with Alexander stain, in vitro germination and hand pollination assays. In the in vitro germination assays culture mediums $\mathrm{A}$ and BK were used and the evaluation was based on pollen tube growth rate. The fresh pollen collected during humid period exhibited higher viability then the fresh pollen collected during dry period. In the in vitro germination tests the pollen tube growth was observed for samples of PF and PA in the first 12 hours. The rate of emitted tubes decreased as time of conservation raised. In the in vitro germination and pollinations tests the pollen samples conserved in the refrigerator exhibited higher viability than those on the nitrogen. The pollinations made with PF and PA pollen that were collected both in the humid and dry period resulted in fruit settings. There was no fruit set from pollinations made with any other pollen sample that was conserved either in nitrogen or refrigerator for more than three days.

Key words: Cryopreservation, Alexander staining, in vitro pollen germination, pollen viability.

\section{INTRODUÇÃO}

A família Annonaceae compreende, aproximadamente, 132 gêneros e mais de 2.300 espécies (Jessup, 1988). Dentre elas, aproximadamente 50 espécies possuem frutos comestíveis (Gardiazabal e Rosemberg, 1993). As anonáceas de maior importância comercial são a pinha, fruta-do-conde ou ata (Annona squamosa L.), a graviola (Annona muricata L.), a cherimóia (Annona cherimola Mill.) e a atemóia (híbrido entre pinha e cherimóia), sendo de menor expressão a condessa (Annona reticulata L.) e o beribá (Rollinia mucosa Baill.) (SÃo José et al., 1997). A cherimóia é nativa da região andina do Peru e Equador e a pinha da América Central, ambas as espécies possuem frutos compostos, chamados sincarpo, formados pela união de numerosos carpelos (DonADIO et al., 1998). O híbrido atemóia foi obtido na Flórida, em 1908, através do cruzamento artificial entre as espécies A. cherimola e $A$. squamosa e apresenta maior amplitude térmica para a adaptação, em relação aos parentais (ToKUnAgA, 2000). Segundo PINTO et al. (2005), as flores dessas anonas apresentam dicogamia protogínica, um mecanismo natural para impedir a autofecundação, e no qual o gineceu se torna receptivo antes da maturação do androceu, quando então ocorre a liberação do pólen.

A polinização natural nestas anonas não é eficiente (MELo, 2001), pois a polinização por insetos é rara e geralmente incompleta, o que gera poucos frutos e muitos deles defeituosos. Portanto, em termos comerciais, a polinização é o principal problema na produção dessas frutíferas, o que tem também dificultado cruzamentos efetivos para a obtenção de novas variedades híbridas. Outro problema relacionado à polinização nessas fruteiras é a curta viabilidade do pólen depois de retirado da planta (Bonaventure, 1999; Pinto-Maglio, 2003). PintoMAGLIO (2003) relata perdas de viabilidade de $70 \%$ a $80 \%$ em amostras de pólen que são colhidos e armazenados por breves períodos (12 horas) para posterior utilização.
A conservação de pólen pode possibilitar a sincronia artificial entre a dispersão de pólen com a receptividade floral, já que o pólen pode ser empregado a qualquer tempo e também para complementar a ação de agentes polinizadores pouco eficientes ou mesmo inexistentes (Tighe, 2004). Outros fatores proporcionados pela conservação do pólen são a preservação de germoplasma, o desenvolvimento de pesquisas com pólen, a promoção de intercâmbio de germoplasma e melhoria da eficiência dos programas de melhoramento (HANNA, 1994). Estudos sobre técnicas e condições de armazenamento do pólen, preservando ao máximo sua viabilidade, têm sido realizados para diversas espécies frutíferas (HoNDA et al., 2002; BOYDEN e Cousins, 2003).

Este trabalho teve como objetivo estudar o efeito de métodos de conservação de grãos de pólen de cherimóia (Annona cherimola Mill.), pinha (Annona squamosa L.) e do híbrido atemóia (A. cherimola $\times$ A. squamosa), a fim de aperfeiçoar procedimentos atuais da polinização manual.

\section{MATERIAL E MÉTODOS}

Os estudos de conservação de pólen de anonas comerciais foram realizados com Annona cherimola Mill. (cherimóia) cv Madeira, Annona squamosa L. (pinha) e da atemóia cv Gefner.

As coletas de pólen e os experimentos de polinização foram executados em dois pomares comerciais. Para cherimóia, mais adaptada a climas temperados, foram selecionados pomares localizados no município de Pedra Bela (SP), no sítio Monjolo, situado a $1.030 \mathrm{~m}$ de altitude, latitude $22^{\circ} 47^{\prime} \mathrm{S}$ e longitude $46^{\circ} 47^{\prime} \mathrm{W}$, com temperaturas médias anual máxima e mínima de 24,7 e $12,5^{\circ} \mathrm{C}$, respectivamente. Para pinha e atemóia, que se adaptam a climas mais subtropicais, foram usadas plantações localizadas no município de Lins (SP), do sítio Yassuda, situado a 400 metros de altitude, latitude $21^{\circ} 40^{\prime} \mathrm{S}$ e longitude $49^{\circ} 46^{\prime} \mathrm{W}$. No município de Lins, as temperaturas médias anuais de máximas e mínimas são, 
respectivamente, de 30,1 e $16,7^{\circ} \mathrm{C}$, e o mês mais frio é julho com médias mínimas de $12,3{ }^{\circ} \mathrm{C}$ (PEDRO JúNIOR et al., 1991).

As flores de cherimóia, atemóia e pinha foram coletadas ao atingirem o estádio em que as flores estavam com pólen maduro. Dentre as várias amostras coletadas para os testes de conservação, denominouse de pólen fresco $(\mathrm{PF})$ o pólen não submetido à conservação, o qual foi usado como pólen testemunha.

Para a obtenção de todas as amostras foram coletadas, de forma aleatória, aproximadamente o total de 50 flores, para cada uma das três fruteiras, em cada período analisado. As flores foram depositadas em bandejas plásticas e em seguida peneiradas para separar as anteras, contendo pólen, das demais partes florais. Também foram coletadas flores no estádio de fêmea (GUIRADO et al., 2001) que permaneceram dentro de bandejas plásticas por um período de aproximadamente doze horas para que atingissem a fase de macho, neste caso a maturação do pólen ocorreu fora da planta. Esse pólen foi classificado como pólen amanhecido (PA). Após a ocorrência da antese, a separação das anteras foi feita da mesma forma descrita anteriormente, para o pólen fresco.

O pólen amanhecido foi utilizado nos experimentos de polinização em campo para comparação com o método correntemente empregado pelos produtores nas polinizações. As amostras de pólen foram coletadas em duas condições climáticas: a primeira caracterizada por um período mais seco (novembro) e a segunda por um período relativamente mais úmido (dezembro), nas áreas experimentais Pedra Bela e Lins. Por meio do psicrômetro de Assman, verificaram-se umidades relativas in loco, durante a coleta das flores, em torno de $53 \%$ e $43 \%$ (novembro) e de $91 \%$ e $86 \%$ (dezembro) respectivamente, nos pomares de Pedra Bela e Lins.

Para os testes padrão, o pólen recém-coletado (PF) foi usado imediatamente após a coleta. O pólen amanhecido (PA) foi utilizado somente após 12 horas da coleta. Para os testes de conservação, as amostras de pólen recém-coletado foram transferidas para uma placa de Petri e submetidas à dessecação durante 90 minutos, no interior de um dessecador contendo sílica, conforme descrito por LORA et al. (2006). Após esse procedimento, o pólen dessecado foi acondicionado em microtubos especiais para baixas temperaturas e armazenado em nitrogênio líquido $\left(-196^{\circ} \mathrm{C}\right)$ e em geladeira $\left(4\right.$ a $\left.5{ }^{\circ} \mathrm{C}\right)$. Na geladeira, os microtubos permaneceram fechados em um dessecador contendo sílica e a temperatura foi monitorada com auxílio de termômetro. Parte das amostras do pólen recémcoletado (PF) foi conservada no nitrogênio líquido e em geladeira sem serem submetidas ao dessecamento.
Dessa forma, para os testes de conservação, foram consideradas amostras com os seguintes tratamentos: 1) pólen não dessecado e conservado em nitrogênio (PndN); 2) pólen não dessecado e conservado em geladeira (PndG); 3) pólen dessecado e conservado em nitrogênio (PdN) e 4) pólen dessecado e conservado em geladeira (PdG). O monitoramento da viabilidade do pólen conservado foi feito através de testes de coloração, germinação in vitro e polinização a campo.

Para os testes de coloração foi utilizado o corante Alexander número 2 (ALEXANDER, 1969), onde são considerados viáveis os grãos de conteúdo corado e inviáveis aqueles com aspecto vazio e sem coloração. Lâminas contendo amostras de pólen, coradas com Alexander, foram aquecidas em chama de lamparina, vedadas com cera e mantidas em geladeira até o momento da análise microscópica. As análises foram feitas em microscópio óptico, em objetiva de aumento 25X. Foram analisados e contados grãos de pólen viáveis e inviáveis, em dez campos aleatórios, por lâmina.

No monitoramento da viabilidade do pólen através de testes de germinação in vitro, foram testados dois meios de cultura denominados A e BK. Ambos compostos por $5 \mathrm{~g}$ de sacarose; $0,87 \mathrm{~g}$ de Agar; 0,01 g de ácido bórico; 0,03 g de nitrato de cálcio; 0,02 g de sulfato de magnésio e 0,01 g de nitrato de potássio, dissolvidos em $100 \mathrm{~mL}$ de água destilada (LorA et al., 2006). No meio A utilizou-se o agar tipo E, da marca Sigma, específico para cultura de tecidos vegetais e, no meio BK, foi usado o bacto-agar Mikrobiolie, da marca Merck. Os meios foram homogeneizados em forno microondas (potência média por 3 minutos) e após o resfriamento, vertidos sobre lâminas de vidro para microscopia, formando uma fina película sobre elas. Em seguida, amostras de pólen foram depositadas sobre as lâminas com auxílio de um pincel. As lâminas foram incubadas em placas de Petri com papel filtro umedecido, formando uma câmara úmida, e mantidas em temperatura ambiente. Para a contagem do número de grãos de pólen germinados utilizou-se o mesmo microscópio e número de campos de observação descritos anteriormente. Foram considerados viáveis os grãos de pólen que emitiram tubo polínico com o comprimento igual ou superior ao diâmetro dos mesmos.

Para estimar a viabilidade do pólen foram também efetuadas polinizações em campo. A fim de evitar uma possível contaminação com pólen estranho, protegeram-se previamente as flores que estavam no estágio de pré-fêmea. Com auxílio de um pincel, efetuaram-se polinizações manuais em flores fêmeas, utilizando-se pólen com os quatro tratamentos (PndN, PndG, PdN e PdG), além do pólen testemunha (PF) e do PA. 
Após as polinizações, as flores foram devidamente identificadas quanto ao pólen utilizado e novamente protegidas com saquinhos de material sintético (tecido não tecido - TNT), os quais foram mantidos nas flores durante 36 horas após o recebimento do pólen. Quinze dias após as polinizações, 11 flores para cada tratamento/ repetição, foram analisadas quanto à fixação de frutos. Foram consideradas viáveis as amostras de pólen que resultaram em frutificações.

Análises estatísticas comparativas foram realizadas para avaliar os efeitos dos diferentes fatores que foram considerados nos experimentos de conservação. Os fatores considerados nessas análises foram: período de coleta (seco e úmido), meio de cultura (A e BK), pólen padrão (PF), pólen amanhecido (PA) e pólen conservado (PndN, PndG, PdN e PdG), germinação in vitro, frutificação resultante da polinização em campo, pré-tratamento (pólen dessecado e não dessecado) e condições de conservação (temperatura de geladeira e de nitrogênio líquido.

Na primeira análise experimental, foi aplicado o delineamento completamente casualizado com tratamentos em arranjo fatorial $2 \times 2 \times 2$, considerando os seguintes fatores para comparação: período de coleta (seco e úmido) de pólen, o meio de germinação (A e BK) e o pólen (PF e PA), respectivamente. $\mathrm{Na}$ segunda análise, o delineamento experimental aplicado foi o completamente casualizado com tratamentos em arranjo fatorial $2 \times 4$, sendo o primeiro fator o período de coleta (seco e úmido) de pólen, o segundo, os tratamentos (PndN, PndG, PdN e PdG). Nas análises, os dados foram submetidos à análise de variância, sendo as médias analisadas através do teste de Tukey, a 5\%. Todas as análises foram resultantes da coleta de dados de quatro repetições.

\section{RESULTADOS E DISCUSSÃO}

Analisando-se inicialmente os dados obtidos nos testes de coloração, pode-se constatar que o pólen fresco (pólen padrão) das três anonas foi aquele com maior porcentagem de viabilidade, o que de certa forma era esperado pelo fato de ter sido considerado o pólen testemunha ou pólen padrão (Tabela 1). Com relação aos tratamentos de conservação, as amostras de pólen coletadas em período úmido, de forma geral, tiveram melhor desempenho em todos os testes aplicados (Tabelas 2, 6, e 8). Pinto-Maglio (2003) relata perdas de viabilidade de 70 a $80 \%$ em amostras de pólen que são colhidos e armazenados por breves períodos (12 horas) para posterior utilização. Segundo BatTISTIN et al. (2006), é provável que existam fatores ambientais que atuem nos genes responsáveis pelo desenvolvimento normal no processo da formação dos gametas masculinos, e no caso das anonas aqui estudadas a umidade seria, provavelmente, um desses fatores. Esta informação tem importância prática para os produtores, como recomendação para a instalação de pomares para essas fruteiras em locais mais úmidos, ou que, em pomares já formados, utilizem a prática de irrigação na época da floração, preferencialmente por aspersão. Outra sugestão seria no sentido do produtor utilizar preferencialmente pólen coletado em períodos úmidos para a realização da polinização manual. SAAVEDRA (1977) observou que a aspersão de água em flores de cherimóia recém polinizadas aumentou a fixação de frutos. O autor relacionou essa maior frutificação à redução do efeito da desidratação do pólen e estigma das flores, uma vez que o trabalho foi realizado em período seco do ano. Assim, outra sugestão, seria o escalonamento na produção de flores/frutos através de podas em períodos mais secos do ano associados sempre à prática de irrigação.

Com relação aos diferentes tratamentos de conservação empregados, observou-se com o teste de coloração, que a maior porcentagem de grãos de pólen viáveis encontrava-se em amostras de pólen, de cherimóia, sem dessecamento e conservadas em nitrogênio líquido (Tabela 2). Para a atemóia e pinha, a maior porcentagem foi observada em amostras de pólen dessecado e armazenado em nitrogênio líquido (Tabela 2). Verificou-se que a maioria dos grãos de pólen (PF e PA), de atemóia, cherimóia e pinha permanecem na sua maioria agrupados na forma de tétrades desde a fase de micrósporo até a sua completa maturação, ou seja, quando já possuem inclusive uma parede bastante espessa, como pode ser verificado, principalmente, nas Figuras 1D e 2D. Dentre as fruteiras testadas, constatou-se que a atemóia foi a que apresentou menor porcentagem de tétrades e porcentagem significativa de tríades $(15 \%)$ e díades $(12 \%)$, quando comparada às demais. Já para cherimóia e pinha, observou-se em média a presença de $90 \%$ de tétrades nas amostras de grãos de pólen avaliados (Tabela 3). Segundo estudos de CopenHAVER (2005), a formação de tétrades é a mais comum nas anonáceas e sua presença, segundo Flores (2002), pode estar relacionada com a maior fertilidade de grãos de pólen.

A presença de díades e mônades foi relativamente baixa em amostras de pólen avaliadas para as três anonas. $\mathrm{O}$ mesmo foi observado para a porcentagem de grãos de pólen vazios (Tabela 3). Em seu trabalho, Copenhaver (2005) cita também que dentre os 23 gêneros englobando 83 espécies de anonáceas, apenas quatro delas formam mônades. 
Tabela 1. Porcentagens médias de grãos de pólen de atemóia, cherimóia e pinha (fresco e amanhecido) viáveis pelo corante de Alexander, em amostras coletadas em dois períodos (seco e úmido)

\begin{tabular}{|c|c|c|c|c|}
\hline \multirow{2}{*}{ Planta } & \multirow{2}{*}{ Pólen } & \multicolumn{2}{|c|}{ Período } & \multirow{2}{*}{ Média } \\
\hline & & Seco & Úmido & \\
\hline \multirow[t]{3}{*}{ Atemóia (1) } & Amanhecido & $80,78 \mathrm{Bb}$ & $82,41 \mathrm{Ba}$ & $81,60 \mathrm{~B}$ \\
\hline & Fresco & $82,80 \mathrm{Ab}$ & $89,19 \mathrm{Aa}$ & $86,00 \mathrm{~A}$ \\
\hline & Média & 81,79 b & 85,80 a & - \\
\hline \multirow[t]{3}{*}{ Cherimóia ${ }^{(2)}$} & Amanhecido & $96,00 \mathrm{Bb}$ & $98,53 \mathrm{Ba}$ & $97,27 \mathrm{~B}$ \\
\hline & Fresco & $98,98 \mathrm{Aa}$ & $99,48 \mathrm{Aa}$ & $99,23 \mathrm{~A}$ \\
\hline & Média & $97,49 \mathrm{~b}$ & $99,01 \mathrm{a}$ & - \\
\hline \multirow[t]{3}{*}{ Pinha ${ }^{(3)}$} & Amanhecido & $88,94 \mathrm{Bb}$ & $89,08 \mathrm{Ba}$ & 89,01 B \\
\hline & Fresco & $93,79 \mathrm{Ab}$ & $94,85 \mathrm{Aa}$ & $94,32 \mathrm{~A}$ \\
\hline & Média & $91,37 \mathrm{~b}$ & $91,97 \mathrm{a}$ & - \\
\hline
\end{tabular}

Para cada planta, médias seguidas de letras maiúsculas iguais na coluna e letras minúsculas iguais na linha não diferem significativamente pelo teste Tukey a $5 \%$.

(1) DMS pólen e período $=0,75$. DMS desdobramento $=1,85$.

(2) DMS pólen e período $=0,74$. DMS desdobramento $=1,42$.

(3) DMS pólen e período $=0,56$. DMS desdobramento $=1,85$.

Tabela 2. Porcentagens médias de grãos de pólen de atemóia, cherimóia e pinha viáveis pelo corante de Alexander, em amostras submetidas a diferentes tratamentos e coletadas em dois períodos (seco e úmido)

\begin{tabular}{|c|c|c|c|c|}
\hline \multirow{2}{*}{ Planta } & \multirow{2}{*}{ Tratamento } & \multicolumn{2}{|c|}{ Período } & \multirow{2}{*}{ Média } \\
\hline & & Seco & Úmido & \\
\hline \multirow[t]{5}{*}{ Atemóia ${ }^{(1)}$} & PndG & $73,54 \mathrm{Bb}$ & $78,90 \mathrm{Ba}$ & $76,22 \mathrm{C}$ \\
\hline & PdG & $73,58 \mathrm{Bb}$ & $81,40 \mathrm{Aa}$ & $77,49 \mathrm{~B}$ \\
\hline & PndN & $72,01 \mathrm{Cb}$ & $79,56 \mathrm{Ba}$ & $75,78 \mathrm{C}$ \\
\hline & $\mathrm{PdN}$ & $75,17 \mathrm{Ab}$ & $81,94 \mathrm{Aa}$ & $78,55 \mathrm{~A}$ \\
\hline & Média & $73,57 \mathrm{~b}$ & $80,45 \mathrm{a}$ & - \\
\hline \multirow[t]{5}{*}{ Cherimóia (2) } & PndG & $98,03 \mathrm{Aa}$ & 98,33 Аа & $98,18 \mathrm{~B}$ \\
\hline & PdG & $98,24 \mathrm{Aa}$ & $96,90 \mathrm{Bb}$ & $97,57 \mathrm{C}$ \\
\hline & PndN & $98,27 \mathrm{Ab}$ & 98,91 Аа & $98,59 \mathrm{~A}$ \\
\hline & $\mathrm{PdN}$ & $97,74 \mathrm{Bb}$ & 98,33 Aa & 98,03 B \\
\hline & Média & $98,07 \mathrm{a}$ & $99,11 \mathrm{a}$ & - \\
\hline \multirow[t]{5}{*}{ Pinha ${ }^{(3)}$} & PndG & $80,12 \mathrm{Cb}$ & $85,35 \mathrm{Ca}$ & $82,74 \mathrm{C}$ \\
\hline & PdG & $81,36 \mathrm{Bb}$ & $88,55 \mathrm{Ba}$ & 84,96 B \\
\hline & PndN & $82,38 \mathrm{Ab}$ & $88,35 \mathrm{Ba}$ & 85,36 B \\
\hline & $\mathrm{PdN}$ & $82,82 \mathrm{Ab}$ & $90,42 \mathrm{Aa}$ & $86,62 \mathrm{~A}$ \\
\hline & Média & 81,67 b & 88,16 a & - \\
\hline
\end{tabular}

Para cada planta, médias seguidas de letras maiúsculas iguais na coluna e letras minúsculas iguais na linha não diferem significativamente pelo teste Tukey a 5\%. PndG = pólen não dessecado conservado em geladeira; PdG = pólen dessecado conservado em geladeira; PndN = pólen não dessecado conservado em nitrogênio líquido; PdN = pólen dessecado conservado em nitrogênio líquido.

${ }^{(1)}$ DMS período $=0,51$. DMS tratamento $=0,95$. DMS desdobramento $=1,33$.

(2) DMS período $=0,17$. DMS tratamento $=0,16$. DMS desdobramento $=0,44$.

(3) DMS período $=0,39$. DMS tratamento $=0,73$. DMS desdobramento $=1,02$. 
Tabela 3. Porcentagens médias das formações em amostras de pólen fresco e amanhecido de atemóia, cherimóia e pinha coletadas em dois períodos (seco e úmido)

\begin{tabular}{|c|c|c|c|c|c|c|c|}
\hline \multirow{3}{*}{ Planta } & \multirow{3}{*}{ Formações } & \multicolumn{3}{|c|}{ Pólen fresco } & \multicolumn{3}{|c|}{ Pólen amanhecido } \\
\hline & & \multicolumn{6}{|c|}{ Período de coleta } \\
\hline & & Seco & úmido & média & seco & úmido & média \\
\hline \multirow[t]{6}{*}{ Atemóia } & Tétrades & 62,2 & 73,6 & 67,9 & 56,4 & 63,4 & 59,9 \\
\hline & Tríades & 17,1 & 12,9 & 15,0 & 21,3 & 17,6 & 19,4 \\
\hline & Díades & 13,9 & 9,8 & 11,8 & 14,5 & 12,3 & 13,4 \\
\hline & Mônades & 2,2 & 1,5 & 1,8 & 3,3 & 4,2 & 3,7 \\
\hline & Grãos isolados & 1,2 & 1,1 & 1,1 & 1,3 & 1,3 & 1,3 \\
\hline & Grãos vazios & 3,2 & 1,1 & 2,1 & 3,1 & 1,1 & 2,1 \\
\hline \multirow[t]{6}{*}{ Cherimóia } & Tétrades & 97,2 & 98,2 & 97,7 & 95,3 & 97,3 & 96,0 \\
\hline & Tríades & 2,1 & 1,2 & 1,6 & 3,1 & 1,5 & 2,3 \\
\hline & Díades & 0,2 & 0,4 & 0,3 & 0,0 & 0,5 & 0,2 \\
\hline & Mônades & 0,1 & 0,0 & 0,05 & 0,5 & 0,0 & 0,2 \\
\hline & Grãos isolados & 0,2 & 0,1 & 0,1 & 0,0 & 0,0 & 0,0 \\
\hline & Grãos vazios & 0,3 & 0,1 & 0,2 & 1,2 & 0,7 & 0,9 \\
\hline \multirow[t]{6}{*}{ Pinha } & Tétrades & 89,2 & 97,4 & 93,3 & 79,7 & 92,7 & 86,2 \\
\hline & Tríades & 2,9 & 1,7 & 2,3 & 12,2 & 2,5 & 7,3 \\
\hline & Díades & 6,0 & 0,0 & 3,0 & 5,5 & 2,0 & 3,7 \\
\hline & Mônades & 0,8 & 0,0 & 0,4 & 0,6 & 0,2 & 0,4 \\
\hline & Grãos isolados & 0,3 & 0,2 & 0,2 & 0,4 & 0,5 & 0,4 \\
\hline & Grãos vazios & 0,1 & 0,7 & 0,4 & 2,2 & 2,1 & 2,1 \\
\hline
\end{tabular}

Tabela 4. Porcentagens médias de grãos de pólen germinados in vitro, sobre dois meios de cultura (A e BK), de amostras de pólen de atemóia, cherimóia e pinha coletadas em dois períodos (seco e úmido)

\begin{tabular}{|c|c|c|c|c|}
\hline \multirow{2}{*}{ Planta } & \multirow{2}{*}{ Meio } & \multicolumn{2}{|c|}{ Período } & \multirow{2}{*}{ Média } \\
\hline & & Seco & Úmido & \\
\hline \multirow[t]{3}{*}{ Atemóia (1) } & A & 6,81 Bb & $16,83 \mathrm{Ba}$ & $11,82 \mathrm{~B}$ \\
\hline & BK & $21,22 \mathrm{Ab}$ & $25,43 \mathrm{Aa}$ & $23,32 \mathrm{~A}$ \\
\hline & Média & $14,01 \mathrm{~b}$ & $21,13 \mathrm{a}$ & - \\
\hline \multirow[t]{3}{*}{ Cherimóia (2) } & $\mathrm{A}$ & 26,08 & 29,44 & $27,76 \mathrm{~B}$ \\
\hline & $\mathrm{BK}$ & 30,26 & 33,85 & $32,05 \mathrm{~A}$ \\
\hline & Média & $28,17 \mathrm{~b}$ & 31,65 a & - \\
\hline \multirow[t]{3}{*}{ Pinha (3) } & $\mathrm{A}$ & $13,99 \mathrm{Bb}$ & $18,24 \mathrm{Ba}$ & $16,12 \mathrm{~B}$ \\
\hline & BK & $25,00 \mathrm{Ab}$ & $37,60 \mathrm{Aa}$ & $31,30 \mathrm{~A}$ \\
\hline & Média & $19,40 \mathrm{~b}$ & $27,92 \mathrm{a}$ & - \\
\hline
\end{tabular}

Para cada planta, médias seguidas de letras maiúsculas iguais na coluna e letras minúsculas iguais na linha não diferem significativamente pelo teste Tukey a 5\%.

(1) DMS meio e período $=1,08$. DMS desdobramento $=3,01$.

(2) DMS meio e período $=1,61$.

(3) DMS meio e período $=1,19$. DMS desdobramento $=2,23$. 
Tabela 5. Porcentagens médias de grãos de pólen germinados in vitro, de amostras de pólen de atemóia, cherimóia e pinha (fresco - PF e amanhecido - PA) coletadas em dois períodos (seco e úmido)

\begin{tabular}{|c|c|c|c|c|}
\hline \multirow{2}{*}{ Planta } & \multirow{2}{*}{ Pólen } & \multicolumn{2}{|c|}{ Período } & \multirow{2}{*}{ Média } \\
\hline & & Seco & Úmido & \\
\hline \multirow[t]{3}{*}{ Atemóia (1) } & PA & $12,53 \mathrm{Bb}$ & $18,35 \mathrm{Ba}$ & $15,44 \mathrm{~B}$ \\
\hline & PF & $15,50 \mathrm{Ab}$ & $23,91 \mathrm{Aa}$ & $19,70 \mathrm{~A}$ \\
\hline & Média & $14,01 \mathrm{~b}$ & $21,13 \mathrm{a}$ & - \\
\hline \multirow[t]{3}{*}{ Cherimóia (2) } & PA & 19,93 & 22,53 & $21,23 \mathrm{~B}$ \\
\hline & $\mathrm{PF}$ & 36,41 & 40,73 & $38,59 \mathrm{~A}$ \\
\hline & Média & $28,17 \mathrm{~b}$ & $31,65 \mathrm{a}$ & - \\
\hline \multirow[t]{3}{*}{ Pinha ${ }^{(3)}$} & PA & $17,81 \mathrm{Bb}$ & $24,54 \mathrm{Ba}$ & 21,17 B \\
\hline & $\mathrm{PF}$ & $21,18 \mathrm{Ab}$ & $31,30 \mathrm{Aa}$ & $26,24 \mathrm{~A}$ \\
\hline & Média & $19,40 \mathrm{~b}$ & 27,92 a & - \\
\hline
\end{tabular}

Para cada planta, médias seguidas de letras maiúsculas iguais na coluna e letras minúsculas iguais na linha não diferem significativamente pelo teste Tukey a $5 \%$.

(1) DMS pólen e período $=1,08$. DMS desdobramento $=3,01$.

(2) DMS pólen e período $=1,61$.

(3) DMS pólen e período $=1,19$. DMS desdobramento $=2,23$.

Tabela 6. Porcentagens médias da germinação in vitro de grãos de pólen de atemóia, cherimóia e pinha submetidos a diferentes tratamentos de conservação e coletados dois períodos (seco e úmido)

\begin{tabular}{|c|c|c|c|c|}
\hline \multirow{2}{*}{ Planta } & \multirow{2}{*}{ Tratamento } & \multicolumn{2}{|c|}{ Período } & \multirow{2}{*}{ Média } \\
\hline & & Seco & Úmido & \\
\hline \multirow[t]{5}{*}{ Atemóia ${ }^{(1)}$} & PndG & 6,29 & 8,1 & $7,20 \mathrm{~A}$ \\
\hline & PdG & 6,15 & 7,94 & $7,05 \mathrm{~A}$ \\
\hline & PndN & 4,62 & 5,95 & $5,28 \mathrm{~B}$ \\
\hline & $\mathrm{PdN}$ & 4,6 & 5,78 & $5,19 \mathrm{~B}$ \\
\hline & Média & $5,41 \mathrm{~b}$ & $6,94 \mathrm{a}$ & - \\
\hline \multirow[t]{5}{*}{ Cherimóia (2) } & PndG & 10,94 & 12,18 & $11,56 \mathrm{~A}$ \\
\hline & PdG & 10,31 & 11,91 & $11,11 \mathrm{~A}$ \\
\hline & PndN & 9,02 & 9,67 & $9,34 \mathrm{~B}$ \\
\hline & $\mathrm{PdN}$ & 9 & 9,5 & $9,25 \mathrm{~B}$ \\
\hline & Média & $9,82 \mathrm{~b}$ & $10,81 \mathrm{a}$ & - \\
\hline \multirow[t]{5}{*}{ Pinha ${ }^{(3)}$} & PndG & 7,32 & 11,18 & $9,25 \mathrm{~A}$ \\
\hline & PdG & 7,11 & 10,97 & $9,04 \mathrm{~A}$ \\
\hline & PndN & 6,14 & 9,1 & $7,62 \mathrm{~B}$ \\
\hline & $\mathrm{PdN}$ & 5,7 & 8,92 & $7,31 \mathrm{~B}$ \\
\hline & Média & $6,59 \mathrm{~b}$ & $10,04 \mathrm{a}$ & - \\
\hline
\end{tabular}

Para cada planta, médias seguidas de letras maiúsculas iguais na coluna e letras minúsculas iguais na linha não diferem significativamente pelo teste Tukey a $5 \%$. PndG = pólen não dessecado conservado em geladeira. PdG = pólen dessecado conservado em geladeira. PndN = pólen não dessecado conservado em nitrogênio líquido. PdN = pólen dessecado conservado em nitrogênio líquido.

(1) DMS período $=0,33$. DMS tratamento $=0,61$.

(2) DMS período $=0,89$. DMS tratamento $=1,66$.

(3) DMS período $=0,51$. DMS tratamento $=0,94$. 
Tabela 7. Porcentagens médias da fixação de frutos em flores de atemóia, cherimóia e pinha polinizadas com pólen fresco e amanhecido, coletados em dois períodos (seco e úmido)

\begin{tabular}{|c|c|c|c|c|}
\hline \multirow{2}{*}{ Planta } & \multirow{2}{*}{ Pólen } & \multicolumn{2}{|c|}{ Período } & \multirow{2}{*}{ Média } \\
\hline & & Seco & Úmido & \\
\hline \multirow[t]{3}{*}{ Atemóia (1) } & Amanhecido & 59,08 & 74,99 & $67,04 \mathrm{~B}$ \\
\hline & Fresco & 65,9 & 84,08 & $74,99 \mathrm{~A}$ \\
\hline & Média & $64,49 \mathrm{~b}$ & $79,54 \mathrm{a}$ & - \\
\hline \multirow[t]{3}{*}{ Cherimóia (2) } & Amanhecido & 70,45 & 84,08 & $77,26 \mathrm{~B}$ \\
\hline & Fresco & 86,35 & 95,45 & $90,90 \mathrm{~A}$ \\
\hline & Média & $78,40 \mathrm{~b}$ & 89,77 a & - \\
\hline \multirow[t]{3}{*}{ Pinha ${ }^{(3)}$} & Amanhecido & 61,36 & 77,26 & $69,31 \mathrm{~B}$ \\
\hline & Fresco & 70,45 & 86,35 & $78,40 \mathrm{~A}$ \\
\hline & Média & $65,90 \mathrm{~b}$ & $81,81 \mathrm{a}$ & - \\
\hline
\end{tabular}

Para cada planta, médias seguidas de letras maiúsculas iguais na coluna e letras minúsculas iguais na linha não diferem significativamente pelo teste Tukey a $5 \%$.

(1) DMS pólen e período $=6,55$.

(2) DMS pólen e período $=5,35$.

(3) DMS pólen e período $=5,35$.

Tabela 8. Porcentagens médias da fixação de frutos em flores de atemóia, cherimóia e pinha polinizadas com amostras de grãos de pólen submetidas a diferentes tratamentos de conservação e coletadas em dois períodos (seco e úmido)

\begin{tabular}{|c|c|c|c|c|}
\hline \multirow{2}{*}{ Planta } & \multirow{2}{*}{ Tratamento } & \multicolumn{2}{|c|}{ Período } & \multirow{2}{*}{ Média } \\
\hline & & Seco & Úmido & \\
\hline \multirow[t]{5}{*}{ Atemóia (1) } & PndG & $12,88 \mathrm{Ab}$ & $20,84 \mathrm{Aa}$ & $16,86 \mathrm{~A}$ \\
\hline & $\mathrm{PdG}$ & $12,88 \mathrm{Ab}$ & $17,80 \mathrm{Ba}$ & $15,34 \mathrm{~A}$ \\
\hline & PndN & $10,98 \mathrm{Ab}$ & $15,15 \mathrm{Ca}$ & 13,07 B \\
\hline & $\mathrm{PdN}$ & $10,98 \mathrm{Ab}$ & $15,15 \mathrm{Ca}$ & $13,07 \mathrm{~B}$ \\
\hline & Média & $11,93 \mathrm{~b}$ & $17,24 \mathrm{a}$ & - \\
\hline \multirow[t]{5}{*}{ Cherimóia (2) } & PndG & 24,99 & 28,41 & $26,70 \mathrm{~A}$ \\
\hline & PdDG & 20,46 & 23,49 & 21,97 B \\
\hline & PndN & 15,91 & 18,18 & $17,04 \mathrm{C}$ \\
\hline & $\mathrm{PdN}$ & 15,53 & 17,8 & $16,16 \mathrm{C}$ \\
\hline & Média & $11,93 \mathrm{~b}$ & $17,24 \mathrm{a}$ & - \\
\hline \multirow[t]{5}{*}{ Pinha (3) } & PndG & $16,67 \mathrm{Ab}$ & $23,48 \mathrm{Aa}$ & $20,08 \mathrm{~A}$ \\
\hline & $\mathrm{PdG}$ & $14,77 \mathrm{Ab}$ & $19,32 \mathrm{Aa}$ & 17,05 B \\
\hline & PndN & $11,74 \mathrm{Bb}$ & $15,91 \mathrm{Ba}$ & $13,82 \mathrm{C}$ \\
\hline & PnD & $11,74 \mathrm{Bb}$ & $15,53 \mathrm{Ba}$ & $13,64 \mathrm{C}$ \\
\hline & Média & $13,73 \mathrm{~b}$ & $18,56 \mathrm{a}$ & - \\
\hline
\end{tabular}

Para cada planta, médias seguidas de letras maiúsculas iguais na coluna e letras minúsculas iguais na linha não diferem significativamente pelo teste Tukey a $5 \%$. PndG = pólen não dessecado conservado em geladeira. PdG = pólen dessecado conservado em geladeira. PndN = pólen não dessecado conservado em nitrogênio líquido. PdN = pólen dessecado conservado em nitrogênio líquido.

(1) DMS período $=1,00$. DMS tratamento $=1,86$. DMS do desdobramento $=2,60$.

(2) DMS período $=0,92$. DMS tratamento $=1,72$

(3) DMS período $=0,92$. DMS tratamento $=1,72$. DMS do desdobramento $=2,40$. 
Esse fato parece ter implicação biológica uma vez que tétrades podem estar relacionadas com polinizadores específicos como os besouros nutidolídeos, pois o pólen formado por essas anonas é "pesado" e "pegajoso". Na prática, esse fato tem demandado polinizações manuais em algumas localidades, principalmente onde a população de besouros é pequena ou inexistente. Outro aspecto importante a ser ressaltado é que tanto para atemóia, cherimóia e pinha, as tétrades foram mais freqüentes nas amostras de pólen fresco coletadas no período úmido (Tabela 3). Foram constatados nos testes de coloração (Tabela 1) e germinação in vitro (Tabelas 4 e 5), que as maiores porcentagens de grãos de pólen corados e germinados foram registradas quando foram utilizadas amostras de pólen fresco e coletadas em períodos úmidos.

Comparando a germinação in vitro do $\mathrm{PF}$, em relação ao PA, no mesmo meio de cultura, notou-se maior vigor do $\mathrm{PF}$, constatado pelo rápido crescimento dos tubos polínicos e um crescimento comparativamente maior dos tubos no PF em relação a PA, em um mesmo período de horas (Figuras 1E e 2B). Dessa forma, foi possível observar que o comprimento do tubo polínico do PF, após 1 hora de inoculação, era proporcional ao comprimento atingido pelos tubos polínicos do PA após 3 horas de inoculação, ambos em meio BK (Figuras 2B e 2C). Essa observação pode ser relacionada às menores porcentagens de viabilidade observadas para o PA nos testes de coloração e polinização (Tabela 1 e 7 , respectivamente).

Nos testes de germinação in vitro e polinização em campo, verificou-se que amostras de pólen coletadas no período úmido e conservadas em geladeira, foram aquelas com os melhores índices de viabilidade (Tabelas 6 e 8). Rosell et al. (2006) não observaram diferenças na germinação in vitro de amostras de pólen recolhidas 90 minutos após a deiscência de flores de cherimóia, em relação ao pólen fresco. Porém, 120 minutos após a deiscência, nas amostras já ocorriam redução significativa na porcentagem de germinação in vitro. Esses autores relataram a baixa taxa de germinação in vivo em amostras de pólen coletadas antes da deiscência natural das flores, à desidratação do pólen, relacionando esse fato à importância das últimas horas de maturação do pólen, antes da ocorrência da antese, para seu completo desenvolvimento.

Por meio dos testes de germinação in vitro evidenciou-se que as maiores porcentagens de emissão de tubos polínicos em grãos de pólen (PF e PA) de atemóia, cherimóia e pinha foram obtidos quando as amostras foram inoculadas sobre o meio de cultura
BK devido ao desenvolvimento de maior número de tubos quando comparados aos mesmos testes efetuados em meio A (Tabela 4). A diferença pode ser atribuída aos diferentes ágares utilizados pois, segundo CALDAs et al. (1998), a consistência do meio de cultura depende diretamente da concentração do ágar dentre outros fatores, que pode de certa forma interferir na germinação dos grãos de pólen. Existem várias marcas comerciais disponíveis de ágar que usualmente são utilizadas em concentrações que variam de $0,4 \%$ a $1 \%$ (CALDAS et al., 1998). Também Murashige (1974), ressaltou que a obtenção da consistência adequada para um meio de cultura e a concentração de ágar necessária varia conforme a qualidade do ágar. Segundo SHIVANNA e RANGASWAMY (1992) outros aspectos que devem ser considerados são: períodos de florescimento, horários de coleta de pólen, ambientes e genótipos que também influenciam a germinação do pólen in vitro.

Para as duas temperaturas de conservação (geladeira e nitrogênio), constatou-se que os grãos de pólen conservados na geladeira foram os que mantiveram o maior potencial germinativo (Tabela 6). Constatou-se que, independente da dessecação, nas condições em que foi realizado o experimento, a geladeira foi a que proporcionou maior porcentagem de grãos de pólen germinados. Guirado et al. (2004), observaram que o pólen de cherimóia, retirado de flores macho, melhorava seu desempenho quando conservado em temperaturas entre 3 e $7^{\circ} \mathrm{C}$, em relação ao pólen mantido em temperatura ambiente $\left(20^{\circ} \mathrm{C}\right)$.

Nos testes efetuados para avaliar a viabilidade do pólen, os dados resultantes indicam, em primeiro lugar, a capacidade germinativa do pólen, e de forma indireta, sua capacidade de fecundar. Assim, estas técnicas utilizadas para testar as amostras conservadas são úteis como indicação qualitativa da viabilidade ou capacidade do pólen germinar pois, segundo STANLEY e LinSKENS (1974), nenhum teste é completamente satisfatório, principalmente após o pólen ter sido armazenado. Isto pode ser explicado pelo fato dos testes químicos usarem corantes que reagem com constituintes químicos ou estruturas, cujas presenças podem não refletir a capacidade do grão de pólen germinar. GALLETA (1983) cita que a comparação entre métodos para estimar a viabilidade do pólen, a exemplo dos testes de coloração e germinação in vitro, pode fornecer resultados discrepantes.

Embora não tenham sido observadas diferenças significativas na emissão de tubos polínicos entre amostras de pólen dessecadas e não dessecadas, numa mesma condição de conservação (geladeira e nitrogênio), foram constatadas diferenças entre as duas condições (Tabela 6). 

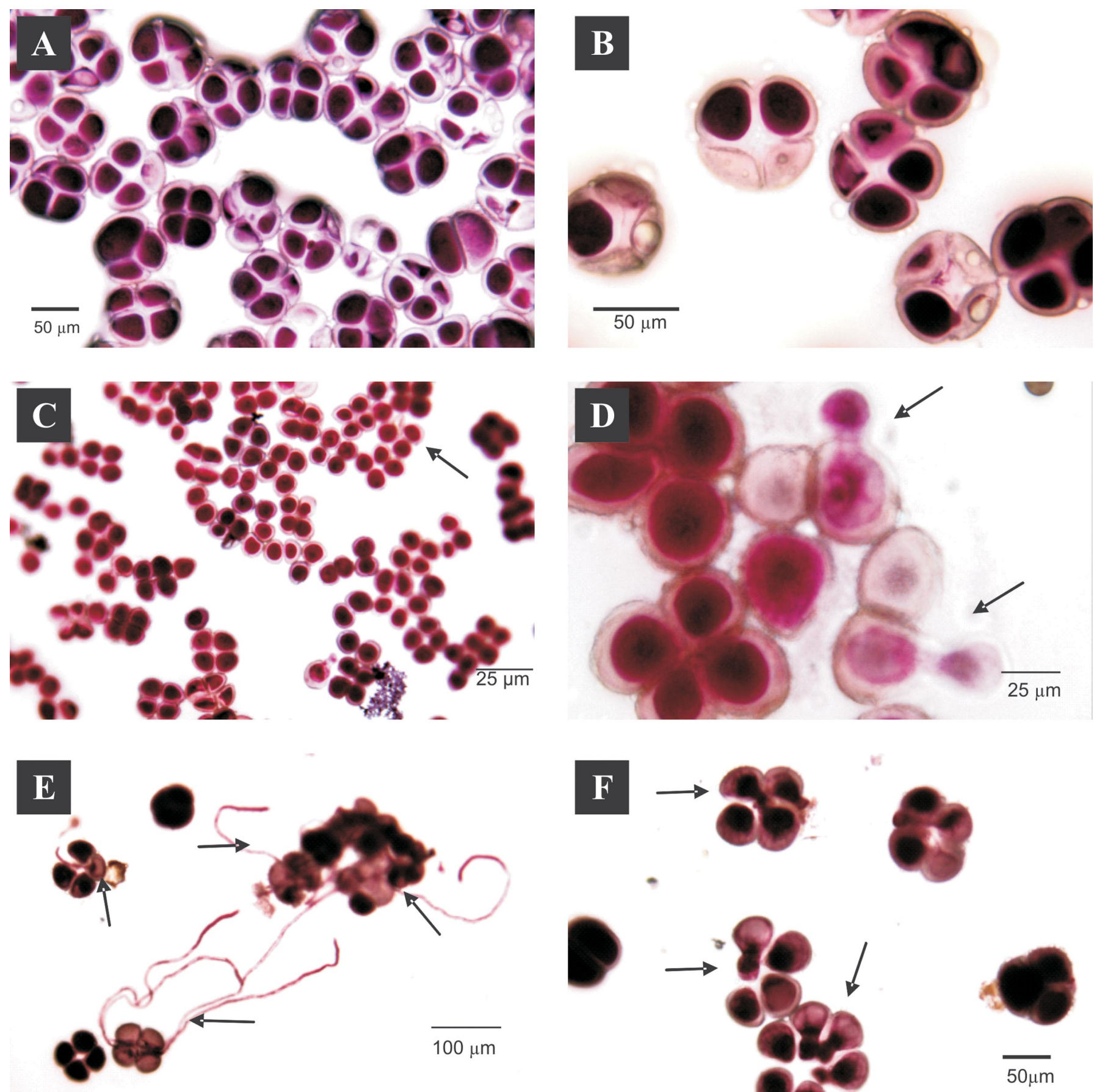

Figura 1. Teste de germinação de pólen maduro em meio A - (A-B) - Tétrades maduras de atemóia cv Gefner. (C-D) Annona squamosa L. (pinha) - grãos de pólen isolados e em tétrade, em início de germinação (setas). (E-F) Annona cherimola Mill. (cherimóia), E - pólen fresco (PF) germinado após 1 hora de inoculação (setas); F - pólen amanhecido (PA) iniciando germinação após 6 horas de inoculação (setas).

As amostras conservadas em geladeira emitiram maior número de tubos em relação às amostras conservadas em nitrogênio.

Esses resultados sugerem que o prétratamento do pólen aplicado neste estudo, parece não ter tido um papel determinante nas condições de conservação testadas. Dessa forma, estudos adicionais relacionados à dessecação poderiam contribuir significativamente para a determinação de uma condição mais adequada para a conservação do pólen dessas fruteiras. Assim, o estabelecimento de tempos diferentes de dessecação para esse pólen, possivelmente, proporcionaria dados sobre teores ideais de umidade para a sua conservação.

Os valores mais elevados das porcentagens de fixação de frutos, para as três anonas, oriundos da 
polinização manual em campo, foram obtidos utilizando-se amostras de pólen coletadas no período úmido e conservadas em geladeira (Tabela 8). Muitos são os fatores que influenciam na germinação do grão de pólen sobre o estigma das flores no campo. Dentre eles, a temperatura e a umidade relativa, são fatores mais importantes (Menzel e Simpson, 1994). MANICA (2003) destaca que o manejo do pólen pode influenciar tanto na germinação como na fixação e frutificação efetiva das flores polinizadas. Hedhly et al. (2005) salientam que elevadas temperaturas aliadas à baixa umidade afetam a cinética do tubo polínico, prejudicando a sua emissão e a taxa de fertilização no campo. Especificamente para Annona squamos, MANicA (2003) relata que ensaios de polinização artificial realizados na Estação Experimental de Macaé (RJ) resultaram em 98\% de frutificação. Esses resultados são similares aos obtidos no presente estudo, onde foram alcançados $86 \%$ de frutificação (Tabela 7). Também em relação à fixação de frutos em pinha, os resultados com pólen fresco foram muito próximos aos $80 \%$ obtidos por Kill e Costa (2003), em polinizações cruzadas, utilizando o pólen da espécie.

As maiores porcentagens de viabilidade verificadas nos testes de germinação in vitro e polinização a campo, neste trabalho, foram para o pólen conservado em geladeira para todas as anonas estudadas (Tabelas 6 e 8). Assim, para curto período de tempo, a geladeira é uma opção viável para as anonas assim como tem sido para a conservação de pólen de diversas outras fruteiras. Por outro lado, Boyden e Cousins (2003), estudando pólen de uva, obtiveram sucesso na conservação e manutenção da viabilidade deste, por prazo superior a um ano, quando mantidos em nitrogênio líquido e ou armazenados a $80{ }^{\circ} \mathrm{C}$. Honda et al. (2002) não obtiveram diferenças significativas entre pólen criopreservado e pólen fresco de Delfinium quanto à quantidade de frutos e sementes, mostrando a viabilidade da criopreservação de pólen. Esses resultados sugerem a possibilidade da criopreservação do pólen das anonáceas aqui avaliadas.
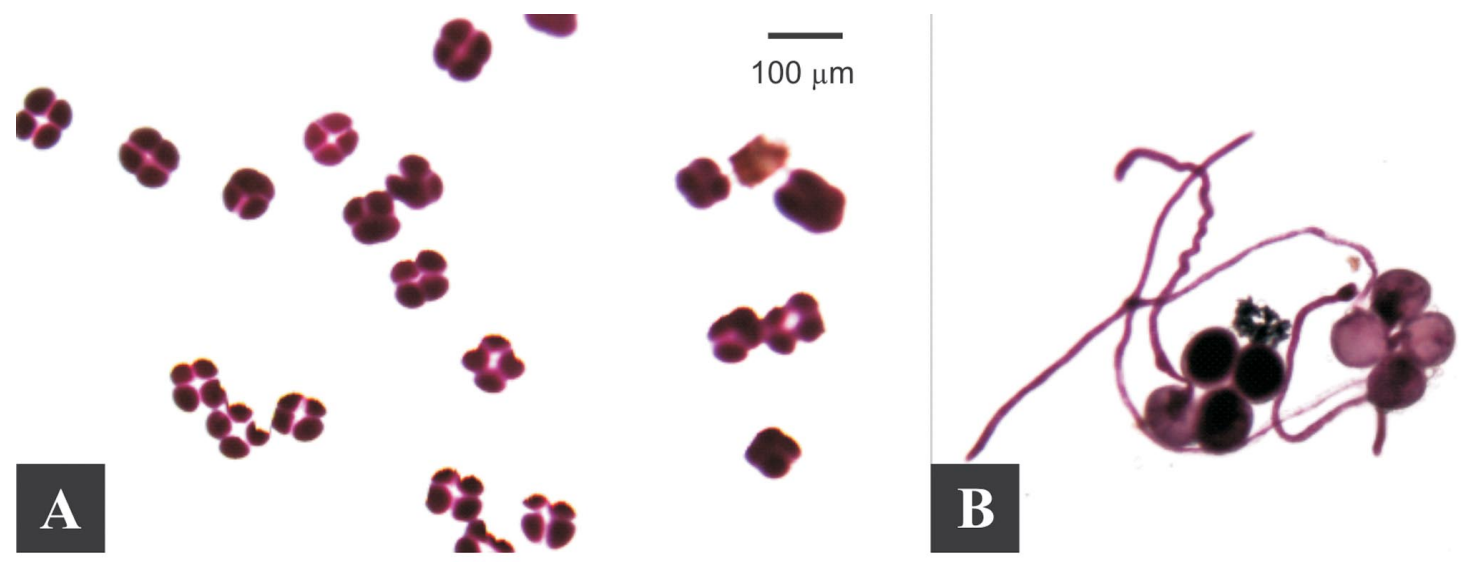

$100 \mu \mathrm{m}$
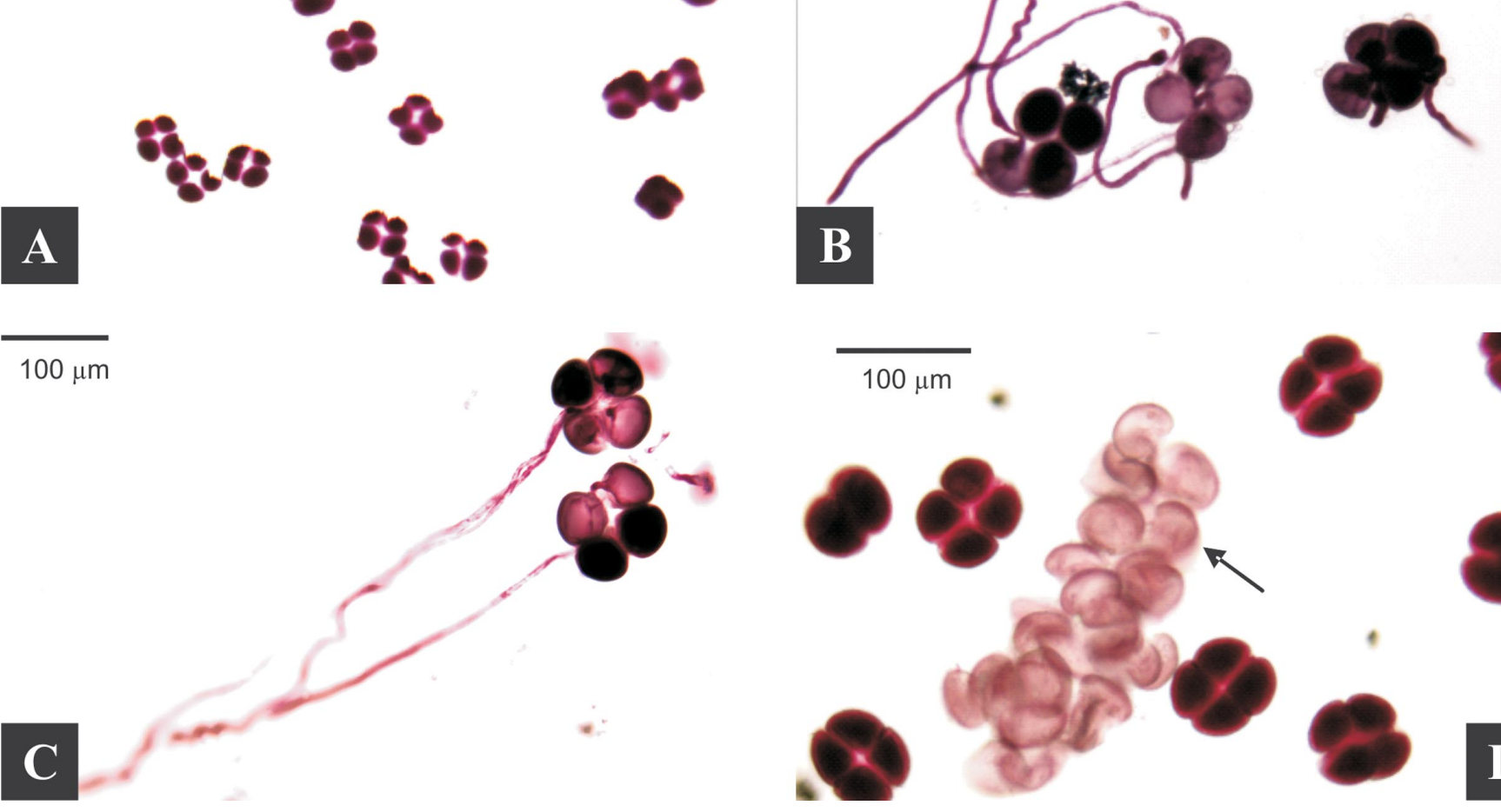

Figura 2. Teste de germinação de pólen maduro de Annona cherimola Mill. (cherimóia). (A-C) - Teste de germinação de pólen maduro amanhecido (PA) e pólen fresco maduro (PF) no meio de cultura BK. A - tétrades (PA) após 1 hora de inoculação; B - tétrades (PA) com tubos polínicos após período de 3 horas de inoculação. C - tétrades (PF) após 1 hora de inoculação. D - Teste de coloração com corante Alexander de pólen fresco (PF) - tétrades coradas e vários conjuntos agrupados vazios - inviáveis (seta). 
Há ainda necessidade de estudos adicionais de conservação para o pólen das anonas aqui avaliadas, relacionados à anualidade de coletas, pois em estudo realizado por SPARKS e YATES (2008) em noz pecã notaram-se diferenças na longevidade e viabilidade em amostras de pólen conservado que haviam sido coletadas em anos sucessivos.

\section{CONCLUSÕES}

1. A utilização do nitrogênio líquido não foi eficiente pois seu uso, quando comparado à geladeira, não implica aumento da longevidade do pólen das anonas estudadas.

2. O pólen fresco nas três fruteiras estudadas possui as maiores taxas para as características de vigor, viabilidade e longevidade.

3 .O meio BK é o meio de cultura mais adequado para a avaliação da germinação in vitro do pólen das espécies e do híbrido estudados.

4. O tempo de dessecação de 90 minutos, nos três materiais estudados, não influencia a viabilidade ou a longevidade do pólen.

5. Nas anonas há predominância de formação de micrósporos que permanecem agrupados em tétrades até o estádio de grãos de pólen maduros.

6. O pólen de pinha, cherimóia e atemóia coletado no período úmido revela maior fecundidade.

\section{AGRADECIMENTOS}

Aos fruticultores Minoru Yassuda, Emília Yassuda, Francisco Rubiño Gomes e Antonio Rubiño Pontes, pela cessão dos pomares e imprescindível apoio prestado durante a realização das etapas de campo dos experimentos.

\section{REFERÊNCIAS}

ALEXANDER, M.P. Differential staining of aborted and nonaborted pollen. Stain Technology, v.62, p.107-112, 1969.

BATTISTIN, A.; CONTERATO, I.F.; PEREIRA, G.M.; PEREIRA, B.L.; SILVA, M.F. da. Biologia floral, microsporogênese e número cromossômico em cinco espécies de plantas utilizadas na medicina popular no Rio Grande do Sul. Revista Brasileira de Plantas Medicinais, v.8, p.56-62, 2006.

BONAVENTURE, L. A cultura da cherimóia e de seu híbrido a atemóia. 1.ed. São Paulo: Nobel, 1999. 182 p.

BOYDEN, L.E.; COUSINS, P. Evaluation of grape pollen viability after freezing in liquid nitrogen and prolonged storage at $-80^{\circ} \mathrm{C}$. In: ANNUAL MEETING OF AMERICAN
SOCIETY FOR ENOLOGY AND VITICULTURE, 54., 2003, Reno. Anais... Reno: ASEV, 2003. v.1, p.65.

CALDAS, L.S.; HARIDASAN, P.; FERREIRA, M.E. Meios nutritivos. In: TORRES, A.C.; CALDAS, L.S.; BUSO, J.A. (Ed.). Cultura de tecidos e transformação genética de plantas. 1.ed. Brasília: EMBRAPA; CBAB, 1998. v.1, p. 87-132.

COPENHAVER, G.P. A compendium of plant species producing pollen tetrads. Journal of the North Carolina Academy of Science, v.121, p.17-35, 2005.

DONADIO, L.C.; NACHTIGAL, J.C.; SACRAMENTO, C.K. do. Frutas Exóticas, 1. Ed. Jaboticabal: FUNEP, 1998. 279p.

FLORES, E.M. Seed Biology. In: Tropical Tree Seed Manual. Vozzo, J.A. (Ed.). Washington: USDA Forest Service, 2002. n. 721, p.13-41. (Agricultural Handbook)

GALLETA, G.J. Pollen and seed management. In: MOORE, J.N.; JANICK, J. Methods in fruits breeding. Indiana: Purdue University Press, 1983. p.23-47.

GARDIAZABAL, F.I.; ROSEMBERG, G.M. El cultivo Del chirimoyo. Valparaíso: Ediciones Universitarias de Valparaíso, 1993. 145p.

GUIRADO, E.; HERMOSO, J.M.; PÉREZ de OTEYZA, M.A; FARRÉ, J.M. Introdución al cultivo del cherimoyo. Granada: Finca Experimental "La Nacla”, Caja Rural de Granada, 2004. p.78.

GUIRADO, E.; HERMOSO, J.M.; PÉREZ de OTEYZA, M.A; GARCÍA-TAPIA, J.; FARRÉ, J.M. Polinización del cherimoyo. Granada: Finca Experimental "La Nacla", Caja Rural de Granada, 2001. p.52.

HANNA, W.N. Pollen storage in frostless and conventional frost-forming freezers. Crop Science, v.34, p.1681-1682, 1994.

HEDHLY, A.; HOMAZA, J.I.; HERRERO, M. The effect of temperature on pollen germination, pollen tube growth, and stigmatic receptivity in peach. Plant Biology, v.7, p.476-483, 2005.

HONDA, K.; WATANABE, H.; TSUTSUI, K. Cryopreservation of Delfiniun pollen at $-30{ }^{\circ} \mathrm{C}$. Euphytica, v.126, p.315-320, 2002.

JESSUP, L.W. Australian Annonaceae in an Asian-Pacific context. Proceedings of the Ecological Society of Australia, v.15, p.24957, 1988.

KIIL, L.H.P.; COSTA, J.G. da. Biologia floral e sistema de reprodução de Annona squamosa L. (Annonaceae) na região de Petrolina-PE. Ciência Rural, v.33, p.851-856, 2003.

LORA, M.A.J.; OTEYZA, P. de; FUENTETAJA, P.; HORMAZA; J.I. Low temperature storage and in vitro germination of cherimoya (Annona cherimola Mill) pollen. Scientia Horticulturae, v.1, p. 91-94, 2006.

MANICA, I. Taxonomia, morfologia e anatomia. In: Manica, I. (Ed). Frutas anonáceas: ata ou pinha, atemólia, cherimólia e graviola. Tecnologia de produção, pós-colheita e mercado. Porto Alegre: Cinco Continentes 2003. p. 23-64. 
MELO, M.R. Polinização natural e artificial da cherimóia e da atemóia no Estado de São Paulo. 2001. 62f. Dissertação (Mestrado em Agricultura Tropical e Subtropical) - Instituto Agronômico, Campinas.

MENZEL, C. M.; SIMPSON, D. R. Passionfruit. In: SCHAFFER, B.; ANDERSEN, P. C. (Ed.). Handbook of environmental physiology of fruit crops: Subtropical and tropical crops. [S.1.]: CRC Press, 1994. v.2 p. 225-241.

MURASHIGE, T. Plant propagation through tissue cultures. Annual Review of Plant Physiology, v.25, p.135-166, 1974.

PEDRO JÚNIOR, M.P.; MELLO, M.H.A.; ORTOLANI, A.A.; ALFONSI, R.R.; SENTELHAS, P.C. Estimativa das temperaturas médias mensais das máximas e mínimas para o Estado de São Paulo. Campinas: Instituto Agronômico,1991. p.11. (Boletim Técnico IAC, n.142)

PINTO, A.C.Q.; CORDEIRO, M.C.R.; ANDRADE, S.R.M. de; FERREIRA, F.R.; FILGUEIRAS, H.A. de; ALVES, R.E. \& KIMPARA, D.I. Annonas Species. International Centre of Underutilised Crops, University of Sounthampton, Sounthampton, UK, 268p, 2005.

PINTO-MAGLiO, C. A. F. Análises de pólen de atemóia. Campinas: Instituto Agronômico, 2003. (Relatório Científico)

ROSELL, P.; SAÚCO, V.G.; HERRERO, M. Pollen germination as affected by pollen age in cherimoya. Scientia Horticulturae, v.1, p.97-100, 2006.

SAAVEDRA, E. Influence of pollen grain stage at time of hand pollination as a factor on fruit set of cherimoya. HortScience, v.12, p.117-118, 1977.

SÃOJOSÉ, A.R.;SOUZA,I.V.B.;MORAIS,O.M.;REBOUÇAS, T.N.H. Anonáceas: mercado (pinha, graviola, atemóia e cherimóia). 1.ed. Vitória da Conquista, BA: DFZ/UESB, 1997.310p.

SHIVANNA, K.R.; RANGASWAMY, N.S. Pollen biology. A laboratory manual. 1.ed. Berlin: Springer-Verlag, 1992. 119p.

SPARKS, D.; YATES, I.E. Pecan pollen can be stored fo years. http://www.geocites.com/CollegePark/Campus/3370/ pollen.htmsigrh.sp.gov.br/cgi-bin/bdhm.exe/plu, Acesso em 7 de abril de 2008 .

STANLEY, R.G.; LINSKENS, H. F. Pollen: biology, biochemistry and management. 1.ed. Berlin: Springer-Verlag, 1974. 172p.

TIGHE, M.E. Manual de recolección y manejo de polen de pinus tropicales y subtropicales procedentes de rodales naturales. 1.ed, Raleigh, NC, USA: NC State University 2004. 20p.

TOKUNAGA, T. A cultura da atemóia. Campinas: CATI, 2000. 80p. (Boletim técnico, n.233) 